\title{
Implementation of a Multidisciplinary Professional Skills Course at an Electrical Engineering School
}

\author{
Franc Gider, Borut Likar, Tomaz Kern, and Damijan Miklavcic
}

\begin{abstract}
This paper describes a case study of an innovative approach to teaching at an engineering school. The postgraduate course Project Work and Communication in Research and Development $(R \& D)$ was developed at the Faculty of Electrical Engineering of the University of Ljubljana, Ljubljana, Slovenia. The main aim of the course was to make the entry of young engineering graduates into the business environment as easy as possible. Currently, engineers are facing more and more interdisciplinarity and project work in their daily assignments. The course was designed to remedy any deficiencies in the multidisciplinary professional skills and knowledge of the graduate-level students, and it covered the topics of innovation management, communication in $R \& D$, project management, and problem solving in teams. An end-of-course survey showed positive feedback from participating students. The empirical data (enrollment ratio of students, session attendance ratio, and average student grade) proves that the course met its goal of honing the professional skills of postgraduate engineering students.
\end{abstract}

Index Terms-Communication, education, electrical engineering education, problem solving, project management, research and development (R\&D).

\section{INTRODUCTION}

\section{A. Background and Motivation}

$\mathbf{T}$ HE INCREASING rate of change of technology in recent years, and the increase in interdisciplinarity, means that companies can now rarely be categorized into traditional sectors, and new interdisciplinary sectors have emerged, such as information and communications technology (ICT) or telemedicine, the emerging sector where medical sciences meet ICT. These new sectors are characterized by the so-called "open innovation approach," where new innovative products, technologies, and services emerge as a mix of different technologies. Similarly, research and development projects are no longer isolated processes, but are fully integrated into the corporate and intercorporate business environment. Managing such projects requires special preparation and management, precise project organization, adapted information support,

Manuscript received May 26, 2011; revised September 09, 2011; accepted October 19, 2011. Date of publication November 11, 2011; date of current version July 31, 2012

F. Gider is with the Slovenian Technology Agency, 1511 Ljubljana, Slovenia (e-mail: fgider@siol.net).

B. Likar is with the Faculty of Management, University of Primorska, 6000 Koper, Slovenia (e-mail: borut.likar1@guest.arnes.si).

T. Kern is with the Faculty of Organization Sciences, University of Maribor, 4000 Kranj, Slovenia (e-mail: tomaz.kern@fov.uni-mb.si).

D. Miklavcic is with the Faculty of Electrical Engineering, University of Ljubljana, 1000 Ljubljana, Slovenia (e-mail: damijan.miklavcic@fe.uni-lj.si).

Digital Object Identifier 10.1109/TE.2011.2174238 correct documentation, and a special organizational culture. Professionals of different backgrounds and cultures interact and need to develop a common language.

This paper describes a case study on the implementation of a course with an emphasis on the development of multidisciplinary professional skills in a postgraduate engineering program. It includes the description of a pedagogical approach, course structure, feedback from students, and lessons learned.

\section{B. Engineering Education}

Education systems in most countries are relatively rigid and unable to follow rapid changes in the modern business world. Technical universities are oriented toward teaching technical knowledge rather than business skills. The European Commission is becoming more and more aware of these facts and has published several proposals for improvements in European universities [1], [2]. They are called upon to modernize their governance, management, and mode of operations since increasing international competition demands quality, leadership, and professionalization. A change in orientation from knowledge toward competencies, combined with a strong emphasis on innovation, is necessary. Keeping economic considerations in mind, universities must maintain a strong academic base and the freedom to focus on future challenges.

A concrete step toward change in the European higher education system was the Bologna Declaration, which was signed by all European Ministers of Education in 1999. The idea behind the Declaration was to improve and unify higher education systems in all EU member states. The changes are meant to shift the goal of academia from having students learn the material to training them to tackle real-life problems in the modern business world, and to change the role of faculty members from being knowledge transmitters to being facilitators of student learning [3]. Also, in the US, the Accreditation Board for Engineering and Technology (ABET) recognizes the needs of business and therefore encourages universities to include professional skills into their curricula [4]. An example of this, focused in interdisciplinary project work, was documented by Ivins [5], where undergraduate students gained many intangible benefits such as improved interpersonal skills, positive emotions, and an increase in personal performance and motivation, which resulted in better overall performance. Another innovative and project-based course for technical students was developed by Frank et al. [6]. The students carried out mini-projects that required the design and construction of devices that performed predefined tasks. The authors report that the course helped develop the students' engineering thinking and their intuition and increased their motivation and responsibility. A similar focus 
TABLE I

Percentage of Students in the Postgraduate Program Enrolling In THE EleCtive COURSE

\begin{tabular}{lccc}
\hline \hline Academic year & $\begin{array}{c}\text { No. of } \\
\text { students in } \\
\text { the } \\
\text { program }\end{array}$ & $\begin{array}{c}\text { No. of } \\
\text { students } \\
\text { in the } \\
\text { course }\end{array}$ & $\begin{array}{c}\text { \% of students } \\
\text { selecting } \\
\text { the course }\end{array}$ \\
\hline $2001 / 02$ & 64 & 17 & 26.56 \\
$2002 / 03$ & 73 & 25 & 34.25 \\
$2003 / 04$ & 81 & 22 & 27.16 \\
$2004 / 05$ & 65 & 16 & 24.62 \\
$2005 / 06$ & 71 & 23 & 32.39 \\
$2006 / 07$ & 77 & 45 & 58.44 \\
$2007 / 08$ & 74 & 34 & 45.95 \\
$2008 / 09$ & 82 & 38 & 46.34 \\
\hline Total & 587 & 220 & 37.48 \\
\hline \hline
\end{tabular}

on soft skills was shown at Pennsylvania State University, University Park [7]. As reported by Bilen et al., the goal of the Engineering Entrepreneurship Minor was to build students' life skills so they could succeed within innovative, product-focused, cross-disciplinary teams. The Minor was designed for undergraduate students majoring in engineering, business, or information sciences and technology who aspired to be innovation leaders for new technology-based products and companies. Another interesting article describes a course on system design (a structural approach) focused on scientific style and engineering style [8]. In that author's opinion, communication skills are very important in the multidisciplinary, distributed, engineering environment. The benefits of teamwork between management and engineering students were documented by Eppinger et al. [9].

To prepare students for careers in modern business life, it is not enough to give them new knowledge in the form of "recipes"; rather, they must be taught how to work on real tasks in modern business and solve real-life problems. Several authors report different approaches to teaching "soft skills" at engineering schools. Some recently published approaches include network intelligence [10], creativity and collaboration [11], knowledge technologies [12], action research with evaluative features [13], cognitive science [4], and teamwork in action research [14].

\section{Postgraduate Studies at the Faculty of Electrical Engineering of the University of Ljubljana}

To meet the needs of young graduates preparing to enter the modern business environment, a new interdisciplinary course, Project Work and Communication in Research and Development $(R \& D)$, was developed and introduced at the Faculty of Electrical Engineering at the University of Ljubljana, Slovenia.

At that time, the postgraduate program in Electrical Engineering was being taught at the University of Ljubljana as a two-year "evening school" program leading to a Master's degree. There were 64-82 students enrolled per year, the vast majority of whom were employed; see Table I. Enrollment was open to students who had completed graduate studies (at that time, a program of five years duration) in electrical engineering, computer and information science, or physics and who had average marks of 7.5 on a scale of 1 (negative) to 10 (excellent). The program also led toward further postgraduate studies to obtain a doctoral degree.
In the two-year postgraduate program, students had to collect 120 credits. They had to complete one compulsory course, Selected Topics on Mathematics, and four elective courses. Each course consisted of 60 contact hours and $90 \mathrm{~h}$ of individual work, equivalent to 15 credits. In addition, students had to complete a seminar of 150 h, i.e., 15 credits and a Master's thesis worth 30 credits. The four elective courses were selected by students from 50 different courses offered by the faculty. The course described here, Project Management and Communication in $R \& D$, was the elective course most frequently selected by students.

\section{LEARNING GOAL AND TEACHING APPROACH}

The main goal of the course Project Work and Communication in $R \& D$ was to give students theoretical knowledge and practical experience in effective $R \& D$ project management. To achieve this, different aspects of $R \& D$ project management were studied in depth, covering the complete product development cycle (idea, idea assessment and selection, idea protection, product development, and product on market) as well as cross-phase multidisciplinary supporting aspects such as project management, communication, and teamwork. This included desk research conducted through the study of scientific literature, writing and presenting the results of $R \& D$ work, general project management, creativity, problem-solving, teamwork, innovation management, and intellectual property management.

To make the knowledge gained as practical as possible, the course was taught by an interdisciplinary team of experienced specialists in the fields of project management, written and spoken communication, innovation, and problem solving in teams. Students were also given hands-on experience with tools and were taught a range of practical techniques.

\section{ORganization OF THE COURSE}

The elective course Project Work and Communication in $R \& D$ was launched in the academic year 2002/03 and was taught every second year, which resulted in students from two consecutive years attending each course offering (i.e., in academic year 2002/03, the students from both 2001/02 and 2002/03 were attending the course; the same system was also applied in the following academic years; see Table I). In the four course offerings over eight academic years, a total of 220 students participated in the course.

One course term consisted of 40 contact hours, in addition to which the students worked on their own assignments for approximately $20 \mathrm{~h}$. The contact sessions were carried out in blocks of $4 \mathrm{~h}$ each to optimize the time needed for the completion of the course. The blocks were scheduled on Friday afternoons (3:30-8:30 p.m.) and Saturday mornings (8 a.m-12:30 p.m.), to accommodate the schedules of both students and professors (most of the students were employed full time; also three of the four professors were employed by employers not related to the University of Ljubljana).

The course was divided into four individual modules, which discussed four different but interrelated topics. The details of these modules are explained as follows. 


\section{A. Module A: Innovation Management}

This module included innovation goals, innovation culture, techniques to boost innovation, intellectual property rights (IPR), patents, models, integrated circuit topology, registration procedures for IPR, and use of Web-based related tools. These skills and competencies are not often part of Master's-degree curricula, especially at engineering faculties. The aim of the module was to develop students' creativity and their ability to detect problems and new opportunities; to engender an entrepreneurial, positive attitude toward risk; and to impart other innovation competencies. Other topics covered were strategic change due to innovation and new organizational forms. Similar topics are encompassed within the interdisciplinary program M.Phil. in Innovation, Strategy \& Organization offered at the Judge Business School, University of Cambridge, Cambridge, U.K. [15]. Another comparable program is offered at the Sloan School of Management, Massachusetts Institute of Technology (MIT), Cambridge [16].

\section{B. Module B: Communication in $R \& D$}

This module included an $R \& D$ results presentation, in written form, as a poster and as an oral presentation. In the oral presentation, specific emphasis is laid on the time allotted and the audience, collecting and selecting data and information, deciding on the main message, selecting evidence, preparing visual aids and handouts, planning the presentation and rehearsal, critical evaluation of the performance, and answering questions. For the written reports, basic rules were given for general professional writing [17], but specific emphasis was given to writing scientific papers [18], [19]. Students practiced this by writing an abstract for a paper, which was then assessed by the mentor and by peers with respect to defining the purpose and structure of the abstract, critical evaluation, clarity of writing, structure, and basic rules for writing scientific papers.

\section{Module C: Project Management}

This module included the following: the definition of projects and project management; the project system of mastering company efficiency [20]; project phases; basic and specific project goals; project resource leveling, planning, and scheduling; project monitoring; prediction; decision-making and assessment of R\&D projects; and use of dedicated software packages. Students were encouraged to work on the preparation of multidisciplinary $\mathrm{R} \& \mathrm{D}$ projects and to work in teams to increase their personal performance and motivation [5].

\section{Module D: Problem Solving in Teams}

The aim of the module was to give students the theoretical background and practical experience in completion of tasks in teams. The module was divided into two parts.

- Theory of teamwork, covering the nature of teamwork, team dynamics and the various roles of team members, and the tools and techniques of teamwork. The nature of teamwork was presented according to teamwork theory drawn from lean organization concepts [21], [22]. Team member roles were presented according to the methodology of Kolb [23].
- Presentation and practical examples of the use of the tools and techniques of teamwork. The topics included problem definition, root-cause analysis, definition of potential solutions, decision making on solutions, solution implementation, and business case presentation [22], [24]-[26].

For practical work on exercises, the students were grouped into teams to give them practical experience of teamwork dynamics. The learning style of each student was assessed according to the methodology developed by Kolb [27], and then students were allocated to teams such that each team included all characters (i.e., Experiencing, Reflecting, Thinking, and Doing).

\section{Teaching Methods}

\section{A. Faculty}

The faculty for the course consisted of four professors who came from four different institutions and had extensive experience in the business world in their respective fields (three also run their own firms on a part-time basis). All had engineering as their basic training. The main selection criterion for the professors was their practical experience in their respective fields.

\section{B. Pedagogical Approach}

The course consisted of lectures (approximately $30 \%$ of total workload), case studies $(10 \%)$, practical work in teams $(30 \%)$ and as individuals (10\%), question and answer sessions (10\%), and work on individual assignments (10\%).

The main features of these various teaching techniques were the following.

1) Traditional lectures were combined with modern pedagogical approaches (practical exercises, case studies, the study of examples, discussions, hands-on experiments, role-playing, simulations, etc.).

2) The lecturers are also practitioners. Therefore, they could simply switch between theoretical knowledge and practical experience, which was well accepted by students.

3) A directionality from knowledge toward competence; the study concept was focused on both the education process and on acquiring competencies in areas such as teamwork, project management, problem defining and solving, critical analysis, and creative thinking.

4) A purpose-designed e-learning platform was an integral part of the course [28], through which students could access to up-to-date information about the course, download teaching materials, hold discussions with professors, upload their written reports, review videos of presentation, see exam results, and complete a questionnaire. The professors used the platform to access and give feedback on students' written reports and homework, answer student questions, and access course statistics.

\section{Grading System}

The students' work was evaluated after each of the four assignments given during the course, being awarded a grade between 1 (insufficient) and 10 (excellent). The final grade for each student was the rounded value of the mean grade of all four assignments. Students had an opportunity to improve this 
final grade, if they wished, with an oral exam consisting of theoretical questions from all four modules. If their answers were satisfactory, the final grade was increased by 1 .

\section{Student Assignments}

During the course, the students worked on four individual and/or team assignments:

1) preparing a plan for innovation performance improvement - practical work on topics related to Modules A and $\mathrm{D}$;

2) preparing an abstract for a scientific paper - practical work related to Module B;

3) preparing and performing an oral presentation in front of peers - practical work related to Module B;

4) conceiving and planning an R\&D project- practical work related to Module $\mathrm{C}$.

The assignments are explained in more detail as follows.

\section{A. Assignment 1: Improvement of Innovation Performance}

One important pedagogical approach within the course was practical work: Students carried out a mini-project representing an interesting model for university-industry cooperation. The aim of the assignment was to give students a better understanding of the concept of innovation management (Module A) and to expose them to practical use of the problem-solving cycle (Module D). To adopt the concept to their daily lives, the students were asked to prepare a strategy for business improvement in the organizations in which the students were employed. The concept was based on modern theory, research results, concrete analysis within the company, strategy prepared by the students, and the professors' coaching. It is worth mentioning that the participating professors were experts and active researchers on the case study topic, publishing in international scientific journals as well as being professional advisers with experience in renowned international consulting organizations. This mini-project assignment, similar to those successfully implemented by Frank et al. [6], was executed individually by students, with the help of support teams set up within their respective organizations. The assignment consisted of eight problem-solving steps, which followed the Simplex technique [25].

Step 1) Problem search: Students were asked to perform innovation performance research within their company and to prepare a short evaluation report using the methodology developed by the professors. The main areas of evaluation were the following: vision and strategic aspects of encouraging innovation; defining goals and measuring results; the organizational culture and climate; innovation expenditure; the role of managers; training and developing employees' competencies; organizing the idea management processes; identification of opportunities and generation of inventions; a system of material and immaterial rewards; cooperation for innovation/managing open innovation; the role of communication and sophisticated IT; factors that inhibit innovation; and the measurable results of innovation. Based on the results and theoretical/practical aspects presented in lectures, the students identified any areas where additional efforts could lead to business performance improvement. These areas represented a starting point for the activities of the following steps.

Step 2) Collection of data: In order to be able to solve the problem, students collected relevant data for further analysis (e.g., number of employees, number of employee suggestions implemented in their respective organizations, monetary gains from the implemented suggestions, etc.).

Step 3) Definition of problem: Search for the root causes of the problem. The Ishikawa diagram approach [24] was used to detect the two most important causes for poor performance in the area selected in step 1.

Step 4) Idea collection: Brainstorming for possible solutions of the causes defined in step 3 was performed. Up to 20 different ideas for solutions were listed by the team.

Step 5) The ideas listed in step 4 were evaluated and compared in pairs using the paired comparison analysis technique [26]. Based on the evaluation, one or two ideas were chosen to be implemented.

Step 6) Planning: Preparation of an implementation action plan for the ideas selected in the previous step.

Step 7) Preparation of a presentation of the chosen ideas and action plan to decision-makers in the company. This step also used the experience from Module B (presentations).

Step 8) Action: This step included implementation of the action plan, follow-up, and feedback from the managers.

The students wrote reports on their work on the assignment; these were read by the professors and discussed in a plenary session format.

\section{B. Assignment 2: Preparation of an Abstract for a Scientific Paper}

Students were requested to write an abstract on a research subject or on a topic of their own choice. The title was limited to a maximum of 85 characters including spaces, and the abstracts were to be between 200-250 words long and could be written either in English or Slovenian. This exercise was conducted in various ways. Students either took the existing abstract they had written in Module B and corrected and adapted it according to the instructions given, or they could write another abstract from scratch. Depending on the year and the number of students enrolled in the course, the students then either handed their written assignments to the mentor for commenting and suggestions, or they were asked to exchange them with student colleagues, switch their role from being the author to the reviewer, and grade, point out mistakes, and suggest what could be improved according to theory [17]-[19]. Emphasis was given to clarity, omitting unnecessary words, avoiding synonyms and jargon, using key words consistently, and using consistent order and point of view. In all cases, students were then required to correct their written assignments based on the comments and suggestions given either by their mentor or peers and to hand 
them to their mentor for final evaluation and grading. This mark contributed to the final mark together with marks from other assignments.

\section{Assignment 3: Preparation and Delivery of an Oral Presentation to Peers}

In this assignment, students were asked to prepare a PowerPoint-supported presentation, up to $7 \mathrm{~min}$ long, on a topic of their choice. Generally, they chose the topic presented in their abstracts or just presented their R\&D project. First, their mentor gave extensive instructions on oral presentation and on visual aids such as PowerPoint. The mentor showed students PowerPoint slides he had used himself for various purposes such as conferences or presentations to potential investors. These real-life examples were used for discussion. Once prepared, the students' PowerPoint presentations were loaded on the server, and the individual students gave their presentations in front of small groups of their colleagues ( 10 or less). Presenting in front of a small audience relieved some of the pressure and also allowed for a more thorough analysis of each presentation in a discussion forum. After each individual presentation, an evaluation was performed by the mentor, who also stimulated discussion among students. The quality of slides and graphs and the contrast and size of fonts and graphs were discussed. Emphasis was given to posture, contact with the audience, control of the situation (advancing slides, use of the pointer and microphone), and most importantly the control of time. Students' presentations were video-recorded, synchronized with slides, and then made available to students for them to watch privately to analyze their and their colleagues' presentations. Notes of comments and evaluations by mentors and peers were posted on the private Web site, which facilitated viewing and identifying the most frequent "mistakes." The possibility of seeing themselves presenting was one of the most valuable experiences as reported informally by many students.

\section{Assignment 4: Conception and Planning of an R\&D Project}

$R \& D$ projects eventually have to be integrated in the business (or any other) system. Actually, projects are just a unique way of organizing specific processes. A project's main characteristic, in comparison to the other business processes running in the company or institution, is that it is a nonrepetitive process. Each project requires special preparation, management, governance, precise project organization, adapted information support, correct documentation, and a special organizational culture.

Projects must be managed and led in a special way; everyone involved must be allowed to fully express his or her innovation and creativity while using his or her relevant expert knowledge. On the other hand, a system must be established and managed to provide certain rules for the project participants within a regulated business system. To achieve this, project processes are divided into two groups: main project processes and business project processes.

To manage this interconnected diversity, special attention was paid to the preparation process of the project in lectures and workshops [29]. Students were asked to prepare the concepts for development or research projects to include the definition of the project purpose, objectives, and constraints. In the project charter, each student developed the project content and created the work breakdown structure (WBS) [30]. The results of student work were carefully reviewed and discussed by the mentor.

The second phase of the workshop was held in small teams. Using the MS Project software tool [31], students independently developed project plans based on their concepts. They defined the project phases and project activities, identified the duration of each activity, created a network plan (Gantt charts), and calculated the duration of the project and project calendar. They also identified available resources and assigned them to activities. They optimized the resource load or detected any overload (resource histograms). Finally, the students calculated the cost of the project and the cost dynamics (S-curves) [32]. The project plans were discussed in teams and reviewed by the mentor.

\section{Empirical Data on Course Performance}

\section{A. Student Enrollment}

The data on the percentage of students in the postgraduate program enrolling in the elective course Project Work and Communication in $R \& D$ show an increasing trend over the period of eight academic years; see Table I. This illustrates students' interest in the skills taught in the course. From the enrollment ratio, a conclusion could be drawn that the course was well accepted, being chosen on average by more than one third of all program students. In the last three years, more than half of the program's students have selected this course.

\section{B. Student Attendance}

Course performance was also evaluated on the data of the presence of students in sessions. It is university policy that student attendance at lecture sessions is neither compulsory nor a criterion in their course grade. Nevertheless, the rate of student attendance at sessions of the Project Work and Communication in $R \& D$ course was more than $90 \%$, in comparison to the $50 \%-70 \%$ normal at the noncompulsory postgraduate study sessions. Typically students do not attend course lecture sessions because the lectures are given straight from textbooks. In this case, the fact that only $30 \%$ of the course consisted of lectures, with the rest being practical work, was the main motivation for students to attend the sessions. In fact, analysis of the course evaluation showed that $66.67 \%$ of all students did not miss a single session. Given that these were held on Friday evenings and Saturday mornings, it may be stated that the interest of the students in the course content was relatively high.

\section{Student Grades}

The average grade of all enrolled students was 9.35 over eight years, whereas the overall average grade in the program for the same period was 9.75. This suggests that the students took the course despite the fact that, on average, they could expect a grade below the average obtained in the program. This also could be interpreted to mean that the students were selecting a course that would bring them a lower grade than the average because they were concerned not just for grades but for the skills they would obtain. 
TABLE II

Results of STUdent SURVEY-PART 1: ORganizATION OF THE COURSE

\begin{tabular}{|c|c|c|}
\hline No. & Question & $\begin{array}{l}\text { Average } \\
\text { grade }\end{array}$ \\
\hline 1 & $\begin{array}{l}\text { Does the actual course } \\
\text { content correspond to } \\
\text { the announced content? }\end{array}$ & 4.79 \\
\hline 2 & $\begin{array}{l}\text { Was the course } \\
\text { information given } \\
\text { adequate in content and } \\
\text { timing? }\end{array}$ & 4.55 \\
\hline 3 & $\begin{array}{l}\text { Was the length of the } \\
\text { course adequate (in } \\
\text { terms of days, hours)? }\end{array}$ & 3.79 \\
\hline 4 & $\begin{array}{l}\text { Did you participate } \\
\text { regularly in contact } \\
\text { hours? }\end{array}$ & 4.45 \\
\hline 5 & $\begin{array}{l}\text { Were your expectations } \\
\text { fully met? }\end{array}$ & 4.33 \\
\hline 6 & $\begin{array}{l}\text { Would you choose the } \\
\text { course again, or } \\
\text { recommend it to your } \\
\text { colleagues? }\end{array}$ & 4.73 \\
\hline 7 & $\begin{array}{l}\text { Did the modules }(\mathrm{A}, \mathrm{B} \text {, } \\
\mathrm{C}, \mathrm{D}) \text { have the right } \\
\text { relative proportions? }\end{array}$ & 3.97 \\
\hline 8 & $\begin{array}{l}\text { Is the course "Project } \\
\text { work and } \\
\text { communication in } \\
\text { R\&D" the best of all } \\
\text { courses within the } \\
\text { postgraduate study } \\
\text { program? }\end{array}$ & 4.06 \\
\hline \multicolumn{2}{|c|}{$\begin{array}{l}\text { Average Grade Part } 1 \\
\end{array}$} & 4.33 \\
\hline
\end{tabular}

\section{STUDENT'S SURVEY}

Student satisfaction with the course was evaluated after each course offering by means of a questionnaire, divided into three parts:

- Eight questions about the organization of the course. The students were asked to grade the organization of the course with grades from 1 (poor) to 5 (excellent). The results are shown in Table II.

- Sixteen questions that evaluated each module of the course (four questions per module). The students were asked to grade the modules with grades from 1 (poor) to 5 (excellent). The results are shown in Table III.

- Five open questions, where the students could express their personal opinion and experience in the course. The answers of the students were grouped and are given in Table IV.

The questionnaire results were analyzed and average grades calculated for each question. The findings from each part of the questionnaire are discussed.

\section{A. Part 1: Course Organization}

Results of the first part of the questionnaire are presented in Table II. The best average grade was given to question 1 (Does the actual course content correspond to the announced content?), and the worst average grade to question 3 (Was the length of the course adequate?). The average grade for all questions was 4.33 . The results of the first part of the survey suggest that the course in general met the expectations of the students. The following two questions had average grades lower than 4 .
TABLE III

RESUlts of STUdENT SURVEY-PART 2: EVALUATION OF INDIVIDUAL MODULES OF THE COURSE

\begin{tabular}{ll}
\hline \hline No. & $\begin{array}{l}\text { Question } \\
\text { Module A }\end{array}$ \\
$9 \quad \begin{array}{l}\text { Was the professor well } \\
\text { prepared for the lectures? }\end{array}$ & 4.59 \\
$10 \quad$ Was the professor is an \\
expert in the field?
\end{tabular}

- Question 3-time of the sessions (average grade 3.79). Scheduling the course sessions on Friday afternoons and Saturday mornings was shown to be inconvenient for the students.

- Question 7-the distribution of time between each of the four modules of the course (average grade 3.97). The results of the student survey suggested that Module $\mathrm{C}$ (Project management) should have more emphasis (see Table II and question 20 in Table III). 
TABLE IV

Results of Student Survey-PART 3: Personal ExPerience IN THE COURSE

\footnotetext{
Part 3: Comments - open questions

Question 25: What content could be

omitted?

Answers (groups)

- project management theory

- idea creation theory

- team work theory

Question 26: What content did you miss?

Answers (grouped):

- business plan writing

- more practical work with project

management software tool

- human management, psychology

- management through objectives

Question 27: What positive experiences did you have with the course / professors? Answers (grouped):

- interactive approach with four different professors;

- practical work on cases and exercises;

- relaxed atmosphere, humor during the

sessions;

- real-life cases used as illustration of the content;

- cooperation between professors of four different institutions
}

Question 28: What negative experiences did you have with the course / professors? Answers (grouped):

- timing of sessions (Friday evening,

Saturday morning);

- overlong sessions;

- project management module could be expanded;

- course was too short to cover all the

details of the topics chosen.

Question 29: What other comments would you like to make?

Answers (grouped)

- overall good experience

- the content should be taught at graduate level

- do not regret having chosen the course

Question 5 elicits students' general opinions after completing the course and provides the overall performance metric for the course. The average grade for this question was 4.33 , meaning that $86.6 \%$ of the students think that their expectations of the course were fully met. Such a result suggests that students' expectations were met to a large extent and the course achieved its goal of enhancing the professional skills of the students.

\section{B. Part 2: Evaluation of Individual Course}

The results of the second part of the survey are presented in Table III. The average grade was 4.32. The results suggest that the students see the professors as experts in their respective fields and think them well prepared for the course (average grades for questions $9,10,13,14,17,18,21$, and 22 were more than 4.5). The results of Part 2 also suggest that the time allocated to individual modules should change slightly: Module A should have less time allocated, and Module $\mathrm{C}$ should have more time allocated (questions 12 and 20).

\section{Part 3: Course Content}

In the third part of the survey, Table IV, the answers could be summarized as follows.

Question 25: What content could be omitted?: Students suggested that innovation management and teamwork should receive less focus.

Question 26: What content did you miss?: Less than $10 \%$ of students answered this question. Those who did gave a variety of ideas/wishes suggesting that they missed some nonengineering (mostly managerial) topics during the study. Two of these ideas could be taken into consideration in the future: writing business plans and more practical work with a project management software tool.

Question 27: What positive experiences did you have with the course/professors?: The students liked the interactive approach with four different professors; cases and exercises during the sessions rather than boring lecture-style teaching; the relaxed atmosphere, humor during the sessions; real-life cases used as illustration of the content; and cooperation between professors of four different institutions.

Question 28: What negative experiences did you have with the course/professors?: These included timing of sessions (Friday evening, Saturday morning); overlong (4-h) sessions (an unusual scheduling for a course, chosen to optimize the availability and time yield of the professors); some topics could be expanded to more hours (project management); and the course was too short to cover all the details of the topics chosen.

Question 29: Do you have other comments?: The answers suggested that the students had a very positive experience with the course. Some of the students suggested that other engineering schools should also consider such a course, even at the undergraduate level.

\section{LESSONS LEARNED}

From the analysis of the questionnaire, it can be concluded that the expectations of the students were met to a great extent; this means that the overall goal of the course, of providing professional skills to students in an innovative and interesting way, was achieved.

The students liked the informal and humorous atmosphere of the sessions. The usefulness of the knowledge and experience taught was emphasized by the practical exercises and student teamwork. The disadvantages of the course could be summarized as the timing of the sessions not being convenient and the ratio of hours spent on individual modules needing modification.

During the development and implementation of the course, valuable experience was gained.

- The content of the course was, in general, well accepted. However, the results of the study suggest that students expect a more balanced content (i.e., more emphasis on 
project management and less on innovation management and teamwork).

- The practical and informal teaching approach to the course was well accepted by the students. Students especially liked the hands-on experience with different aspects of R\&D project management.

- The scheduling of contact sessions during weekends was not well accepted since the sessions were too long and were scheduled in the spare time of most of the students (which did, however, allow them to attend course lectures and practical sessions). Since all the students are employed full-time during the course, the most appropriate solution seems to be shorter, perhaps $2-\mathrm{h}$, sessions on weekday evenings.

- Some student answers suggest that the course was too short to cover all important aspects of the respective modules, which led the authors to develop three new undergraduate- and postgraduate-level courses to teach multidisciplinary soft skills at engineering schools. These are the bases for new courses, which divide the content of the course described here into roughly three parts and give a more in-depth coverage of the topics at different levels of the study program at the University of Ljubljana. These three courses are the following:

1) an undergraduate-level course, which covers project management, innovation, and teamwork, to start in academic year 2011/12;

2) an undergraduate-level course, which covers professional communication in research and development, to start in academic year 2013/14.

3) a postgraduate-level course, Communication in Research and Development, that was launched in academic year 2009/10 and covers communication with peers, communication on science with the general public, teamwork, problem solving, and conflict management.

\section{CONCLUSION}

This paper has presented the experience of implementing a new postgraduate-level course, Project Work and Communication in $R \& D$, at the Faculty of Electrical Engineering at the University of Ljubljana. The aim of the course was to give students multidisciplinary professional knowledge as an addition to the technical expertise they acquire during their studies. It was designed to fill the gap that young graduates experience when entering real business life.

The four offerings of the course over eight academic years showed that it was well accepted by students. A general conclusion could be drawn that the course was successfully implemented and achieved its initial goals.

As a result of the implementation of this course, new interdisciplinary courses have been developed for various levels of engineering study programs at the University of Ljubljana.

\section{ACKNOWLEDGMENT}

The authors would like to thank M. Rebernik for her help in data collection and analysis.

\section{REFERENCES}

[1] "Europe's universities must be modernized, says commission," Luxembourg, Luxembourg, Europe Press Release, Jun. 2006, p. 148.

[2] B. Likar, "University-Business dialogue: Could that be a solution?," in Eur. Innov. Minds, J. Zverina, Ed., Brussels, Jan. 29, 2009, pp. $43-52$.

[3] T. Clausen, "Guest editorial: Undergraduate engineering education challenged by the Bologna declaration," IEEE Trans. Educ., vol. 48, no. 2, pp. 213-215, May 2005.

[4] A. Mohan, D. Merle, C. Jackson, and S. S. Nair, "Professional skills in the engineering curriculum," IEEE Trans. Educ., vol. 53, no. 4, pp. 562-571, Nov. 2010.

[5] S. J. R. Ivins, "Interdisciplinary project work: Practice makes perfect?," IEEE Trans. Educ., vol. 40, no. 3, pp. 179-183, Aug. 1997.

[6] M. Frank, I. Lavy, and D. Elata, "Implementing the project-based learning approach in an academic engineering course," Int. J. Tech. Design Educ., vol. 13, pp. 273-288, 2003.

[7] S. G. Bilen, E. C. Kisenwether, S. Rzasa, and J. Wise, "Developing students' entrepreneurial skills and mindset," J. Eng. Educ., vol. 94, no. 2, pp. 233-243, 2005.

[8] M. S. Levin, "Course system design: A structural approach," in Proc. 18th DTM (IDETC/CIE), 2006, vol. 4a, pp. 475-484, DETC2006-99547.

[9] D. Eppinger, C. H. Fine, and K. T. Ulrich, "Interdisciplinary product design education," IEEE Trans. Eng. Manag., vol. 37, no. 4, pp. 301-305, Nov. 1990.

[10] J. Palmer, "The human organization," J. Knowl. Manag., vol. 1, no. 4, pp. 294-307, 1998.

[11] A. B. Burns and T. M. Jordan, "Learning to see the (w)holes," Ind. Higher Educ., vol. 20, no. 1, pp. 15-18, Feb. 2006.

[12] T. Urbancic, "From fragments of knowledge toward a bigger picture: How can the process be supported," Organizacija, vol. 40, no. 6, pp. 263-266, 2007.

[13] C. Savander-Ranne, O.-P. Lunden, and S. Kolari, "An alternative teaching method for electrical engineering courses," IEEE Trans. Educ., vol. 51, no. 4, pp. 423-431, Nov. 2008.

[14] F. Gider and T. Urbancic, "Developing soft skills for engineering: Experience with student team projects," Organizacija, vol. 43, no. 1, pp. 35-39, 2010.

[15] "The MPhil in innovation, strategy \& organisation," Judge Business School, University of Cambridge, Cambridge, U.K., Sep. 2011 [Online]. Available: http://www.jbs.cam.ac. uk/programmes/mphil_innovation/programme/index.html

[16] "MIT Sloan Fellows Program in innovation and global leadership," MIT Sloan, Cambridge, MA, Sept. 2011 [Online]. Available: http:// mitsloan.mit.edu/fellows/advantages/

[17] M. Markel, Writing in the Technical Fields. Piscataway, NJ: IEEE Press, 1994.

[18] D. Miklavčič, "Publishing research results—Scientific paper writing," (in Slovenian: Objavljanje rezultatov raziskav-Pisanje člankov) Elektroteh. Vestn., vol. 77, pp. 75-84, 2010.

[19] M. Wiess and A. M. Newman, "A guide to writing articles in energy science," Appl. Eng., vol. 88, no. 11, pp. 3941-3948, 2011.

[20] B. Urh and M. Roblek, "A system for mastering company efficiency," in Proc. 24th Int. Conf. Org. Sci. Dev., Portoroz, Slovenia, 2005, pp. 1013-1020.

[21] J. P. Womack, D. T. Jones, and D. Roos, The Machine That Changed the World. New York: Rawson, 1991, pp. 113-115.

[22] T. McCarty, L. Daniels, M. Bremer, and P. Gupta, Six Sigma Black Belt Handbook. New York: McGraw-Hill, 2005.

[23] D. A. Kolb, Kolb Learning Suite - Facilitator's Guide to Learning. Philadelphia, PA: Hay Group, 2009.

[24] W. J. Michalski, Six Sigma Tool Navigator: The Master Guide for Teams. New York: Productivity Press, 2003.

[25] M. Basadur, The Power of Innovation: How to Make Innovation a Way of Life \& How to Put Creative Solutions to Work. Toronto, ON, Canada: Applied Creativity Press, 1995.

[26] “The Mind Tools full toolkit,” Mind Tools, Swindon, U.K., Sept. 2011 [Online]. Available: http://www.mindtools.com

[27] D. A. Kolb, Kolb Learning Style Inventory. Philadelphia, PA: Hay Group, 2007.

[28] I. Humar, A. R. Sinigoj, J. Bester, and M. O. Hagler, "Integrated component web-based interactive learning systems for engineering," IEEE Trans. Educ., vol. 48, no. 4, pp. 664-675, Nov. 2005.

[29] A Guide to the Project Management Body of Knowledge (PMBOK Guide), 4th ed. Newton Square, PA: Project Management Institute, 2008 . 
[30] M. Roblek, M. Zajec, and T. Kern, "The lack of knowledge? Change the way you work," in Proc. 44th Annu. Hawaii Int. Conf. Syst. Sci., Jan. 4-7, 2011, p. 6.

[31] P. E. Harris, Planning and Scheduling Using Microsoft Office Project 2010. Victoria, Australia: Eastwood Harris, 2010.

[32] J. Ban and V. Tomazin, "The role of the project office in company restructuring from a production to a marketing enterprise," in Book Abstracts 27th Int. Conf. Org. Sci. Dev., Portoroz, Slovenia, 2008.

Franc Gider was born in 1969. He received the B.Sc., M.Sc., and Ph.D. degrees in biomedical engineering from the Faculty of Electrical Engineering, University of Ljubljana, Ljubljana, Slovenia, in 1993, 1996, and 1998, respectively.

He worked as a Junior Researcher with the Jozef Stefan Institute, Ljubljana, Slovenia, from 1994 to 1999 before joining the consulting firm Deloitte, Ljubljana, Slovenia, where he worked as a consultant in the field of process optimization and continuous improvement systems from 1999 to 2005. Then, he founded his own consulting firm, where he worked from 2005 to 2007. Currently, he is Director General of the Slovenian Technology Agency. For the last six years, he has also been a Part-Time Professor with the University of Ljubljana. His main research interests include continuous improvement systems and personal and technology development.

Dr. Gider is member of the Pomurje Academic Society.
Borut Likar was born in 1962. He received the B.Sc., M.Sc., and Ph.D. degrees in biomedical engineering from the Faculty of Electrical Engineering, University of Ljubljana, Ljubljana, Slovenia, in 1986, 1991, and 1994, respectively.

$\mathrm{He}$ is a Managing Director of the Institute for Innovation and Technology as well as an Associate Professor with the Faculty of Management, University of Primorska, Koper, Slovenia, where he also worked as an R\&D Vice-Dean. Furthermore, he actively works at the University of Ljubljana as a university Lecturer. His work encompasses management of creativity, R\&D, technology, and innovation processes in the field of educational systems and industry. Besides this academic work, he is an innovator and initiator and has led many successful research, applied, technological, and other national and EU projects. He is the author of multiple patents, models, and copyright works, of which many have proved to be extremely marketable. Among numerous lectures he has given, his talks at the United Nations' headquarters in Geneva, Switzerland, and at the European Parliament in Brussels, Belgium, were met with a particularly wide response.

Tomaz Kern was born in 1964. He received the B.Sc., M.Sc., and Ph.D. degrees in organizational sciences from the Faculty of Organizational Sciences, University of Maribor, Kranj, Slovenia, in 1990, 1994, and 1998, respectively.

$\mathrm{He}$ is a Professor with the Faculty of Organizational Sciences, University of Maribor, and lectures on business processes and project management. $\mathrm{He}$ is a Researcher with the Institute for Organization and Management, Kranj, Slovenia. He leads a team of experts within the laboratory for process and project management and has been involved in more than 40 projects for Slovene and European companies and institutions. His bibliography includes over 300 scientific and technical papers and articles.

Damijan Miklavcic was born in 1963. He received the Ph.D. degree in electrical engineering from the University of Ljubljana, Ljubljana, Slovenia, in 1993.

$\mathrm{He}$ is a Professor with the Faculty of Electrical Engineering, University of Ljubljana, where he is the Chair of the Department for Biomedical Engineering and also the Head of the Laboratory of Biocybernetics. He is engaged in the field of biomedical engineering. His current research interests include electroporation assisted drug and gene delivery, including cancer treatment by means of electrochemotherapy, tissue oxygenation, modeling of biological processes, and hardware development. 